\title{
PERANCANGAN SISTEM PENELUSURAN ALUMNI (TRACER STUDY) BERBASIS WEB
}

\author{
Eko Nursubiyantoro dan Puryani \\ Jurusan Teknik Industri Fakultas Teknik Industri \\ Universitas pembangunan Nasional "Veteran" Yogyakarta \\ Jl. Babarsari 2 Tambakbayan, Yogyakarta, 55281 Telp/Fak : (0274) 486256 \\ email: eko_nsby072@upnyk.ac.id ${ }^{1)}$,purya_ni@yahoo.co.id ${ }^{2)}$
}

\begin{abstract}
Abstrak
Kualitas lulusan perguruan tinggi ditentukan oleh proses pendidikan yang diselenggarakan program studi dalam mencetak kader-kader intelektual. Karakter lulusan yang baik dibangun dengan proses yang baik oleh program studi bila semua stake holder terlibat dengan tujuan sama membentuk proses pembelajaran pendidikan program studi yang baik. Proses pembelajaran pendidikan dikatakan baik apabila lulusannya dibutuhkan oleh pengguna lulusan, sehingga untuk mencapai taraf tersebut program studi harus tahu keinginan pengguna lulusan dengan melibatkan peran alumni sebagai sumber infomasi. Kontribusi alumni yang baik terhadap sumbangan pemikiran dan finansial kepada program studi akan mempengaruhi perkembangan perguruan tinggi. Penelitian dilaksanakan untuk membangun sistem informasi alumni teknik industri agar membantu pelacakan alumni, melalui tahapan pertimbangan faktor-faktor dalam merancang sistem informasi alumni, mengumpulkan data kebutuhan dan keinginan stakeholders. Hasil penelitian menunjukkan bahwa strategi untuk rancangan sistem informasi alumni harus mempertimbangkan aspek-aspek database, jaringan internet, hosting, coding, dan desain sehingga tampilan sistem informasi dapat menarik stakeholders.
\end{abstract}

Kata kunci: sistem informasi, alumni, rancangan sistem

\section{PENDAHULUAN \\ 1.1 Latar belakang}

Perguruan tinggi yang baik akan terbangun citranya di masyarakat salah satunya ditentukan oleh kualitas lulusannya, sedangkan kualitas lulusan tidak lepas dari usaha-usaha proses pembelajaran pendidikan pada program studi. Program studi dari sebuah perguruan tinggi merupakan ujung tombak terdepan dalam rangka proses pembelajaran guna mencetak kader-kader intelektual calon pemimpin dan penerus generasi bangsa di negara tercinta ini. Program studi harus memiliki skill dan kompetensi yang memadai untuk mewujudkan karakter lulusan yang diharapkan dan sesuai dengan visi misi prodi, fakultas dan universitas. Karakter lulusan yang baik dapat dibangun dengan proses yang baik pada program studi apabila semua stake holder terlibat dengan tujuan sama untuk membentuk suatu proses pembelajaran pendidikan program studi yang baik. Proses pembelajaran pendidikan suatu program studi dikatakan baik apabila lulusannya dibutuhkan oleh dunia kerja pengguna lulusan, sehingga untuk mencapai dalam taraf tersebut maka program studi harus tahu keinginan dari para pengguna lulusan.

Keinginan stake holder pengguna lulusan dapat diketahui dengan menggali informasi tentang kebutuhan skill dan kompetensi lulusan yang siap digunakan didunia kerja. Informasi dapat diperoleh dengan biaya murah apabila program studi dapat mengelola lulusan dengan baik, sejalan dengan standard mutu program studi yang dituangkan dalam butir-butir borang akreditasi program studi sarjana yang diterbitkan oleh Badan Akreditasi Nasional Perguruan Tinggi (BAN-PT). Butir-butir pertanyaan yang harus dijawab dan dilakukan oleh program studi diantaranya adalah umpan balik dari alumni dan pengguna lulusan. Pertanyaan tentang 
adanya studi pelacakan (tracer study) untuk mendapatkan hasil evaluasi kinerja lulusan dengan pihak pengguna, rata-rata waktu tunggu lulusan memperoleh pekerjaan pertama, prosentase lulusan yang bekerja pada bidang sesuai keahliannya, apakah lulusan memiliki himpunan alumni, apa aktivitas dan hasil kegiatan dari himpunan alumni terhadap kemajuan program studi. Peran alumni dalam peningkatan mutu program studi merupakan hal penting yang tidak dapat dipisahkan dari kebutuhan pengelola program studi, kontribusi alumni yang baik terhadap sumbangan pemikiran dan finansial kepada program studi akan mempengaruhi perkembangan perguruan tinggi. Hubungan keberlanjutan antara alumni dan program studi khususnya dibutuhkan metode dan sarana untuk saling memberikan informasi dengan mudah. Pada era milenia ini keterkaitan kedua pihak dapat dengan mudah diwujudkan dengan sistem informasi. Salah satu upaya tersebut adalah dengan membangun sistem informasi alumni, permasalahannya untuk mewujudkan hal tersebut adalah bagaimanakah rancangan sistem informasi alumni yang dapat mendukung pendataan informasi alumni. Tujuan dari penelitian ini adalah merancang sebuah sistem informasi alumni berbasis web dengan harapan diperoleh manfaat tersedianya informasi data-data alumni sehingga membantu dalam pelacakan alumni.

\subsection{Landasan Teori}

Sistem informasi dibangun dalam rangka untuk memudahkan pekerjaan manusia dalam berinteraksi antar manusia, serta mendukung kegiatan untuk pengambilan keputusan dengan cepat. Sistem informasi didefinisikan sebagai suatu sistem yang bersifat manajerial, menyediakan kebutuhan harian olah data transaksi dari kegiatan stategi organisasi dan menyiapkan pihakpihak lain tertentu dalam bentuk laporanlaporan yang diperlukan (Laudon, K. dan Laudon, J., 2007). Berdasar definisi tersebut maka sebuah sistem informasi menjadi penting dalam kegiatan manajerial untuk menentukan langkah-langkah organisasi agar dapat berjalan dengan baik dan benar. Informasi yang digunakan sebagai pendukung kegiatan manajerial ini haruslah informasi yang baik, informasi dikatakan baik apabila informasi bermanfaat sebagai pendukung proses pengambilan keputusan yang diperlukan saat ini maupun untuk keperluan mendatang. Sebuah sistem informasi pada dasarnya adalah menghasilkan informasi yang berupa data yang diolah sedemikian rupa sehingga berguna bagi pemakainya. Sebuah informasi bukanlah berupa data yang hanya cukup diolah saja, akan tetapi informasi haruslah informasi yang baik berkualitas. Informasi yang berkualitas ditentukan oleh 3 hal (Sutabri, 2012) yaitu: accurate, timeliness dan relevance. Akurat (accuracy)artinya sebuah informasi itu harus benar dan tidak bias atau bebas dari kesalahan, tidak menyesatkan. Tepat waktu (Time Lines) artinya informasi harus tersedia sesuai dengan saat dibutuhkannya, tidak boleh terlambat. Informasi yang terlambat akan tidak berguna, apalagi untuk proses pengambilan keputusan akan fatal akibatnya jika terdapat keterlambatan informasi. Relevan (relevance) artinya informasi harus bermanfaat untuk pemakainya, relevansi dari sebuah informasi

berbeda setiap orangnya. Contoh informasi tentang penyebab kerusakan mesin produksi sebuah perusahaan maka tidaklah relevan jika informasi itu disampaikan kepada bagian keuangan, seharusnya untuk disampaikan kepada bagian ahli teknik perusahaan. Inforasi yang tidak didukung oleh hal tersebut tidak dapat dikatakan sebagai informasi yang berguna, tetapi merupakan informasi sampah (garbage).

Komponen - komponen dalam sistem informasi adalah sebagai berikut (Burch dan Grudnitski, dalam Arizyanty, 2009):

a. Hardware, adalah sebuah media penyimpanan yang penting untuk sistem informasi yang tersimpan dalam database agar lancar dan mudah bagi kerja sistem informasi.

b. Software, adalah sebuah perangkat lunak yang fungsinya sebagai wadah untuk mengolah, menghitung, memanipulasi data hardware untuk diubah menjadi informasi. 
c. Prosedur, adalah tatacara atau aturan yang digunakan dipakai untuk memproses data dan membangkitkan output yang diperlukan.

d. Orang

e. Database, adalah pengorganisasian sekumpulan data-data yang saling terkait untuk kemudahan aktivitas memperoleh informasi. Basis data digunakan untuk menyimpan untuk keperluan penyediaan data selanjutnya, basis data diakses dengan menggunakan Database Management System (DBMS).

f. Jaringan komputer dan komunikasi data, adalah sistem penghubung terintegrasi yang memnungkinkan pemakaian sumber secara bersama.

Cross (1989) membagi proses perancangan produk menjadi tujuh tahapan meliputi :

a. Klarifikasi tujuan, metode dalam penyusunan klarifikasi tujuan adalah menggunakan pohon tujuan yang memberikan bentuk dan penjelasan dari pernyataan tujuan untuk menggambarkan tujuan dan sasaran yang akan dicapai dengan berbagai pertimbangan.

b. Penetapan fungsi, bertujuan menetapkan fungsi-fungsi yang diperlukan dan batas-batas sistem rancangan produk yang baru.

c. Penyusunan kebutuhan, bertujuan untuk membuat spesifikasi desain atau rancangan yang akurat dengan metode Performance Specification Model.

d. Penetapan karakteristik, bertujuan menetukan target yang akan dicapai oleh karakteristik teknik suatu produk sehingga memuaskan kebutuhan-kebutuhan konsumen. Metode yang digunakan dalam menetapkan karakteristik adalah Quality Function Deployment (QFD

e. Pembangkitan alternatif, bertujuan menghasilkan solusi rancangan alternatif dengan metode Morphological Chart untuk mendorong para perancang dalam mengidentifikasi kombinasi elemen-elemen yang baru.

f. Evaluasi alternatif, bertujuan memilih yang terbaik dengan cara perbandingan nilai bantu dari berdasarkan kemungkinan bobot yang berbeda-beda menggunakan metode Weighted Objective.

g. Rincian perbaikan, bertujuan mewujudkan rancangan produk dengan pengembangan produk, peningkatan penampilan, pengurangan berat, penurunan biaya, dan peningkatan daya tarik.

Quality Function Development (QFD) adalah proses penterjemahan kebutuhan pelanggan menjadi produk yang dihasilkan oleh organisasi/perusahaan sehingga memungkinkan perusahaan memprioritaskan kebutuhan pelanggan, menemukan masukan yang inovatif dan melakukan perbaikan proses sehingga tercapai efektifitas yang maksimal sesuai keinginan dan dimungkinkan dapat juga melampaui keinginan pelanggan(Akao, 1990; Urban and Hauser, 1993).

Manfaat dari penerapan QFD bagi perusahaan secara kontinyu dalam peningkatan kualitas dan produk adalah sebagai berikut:

a. Fokus pelanggan, perusahaan yang mengutamakan kualitas akan fokus pada kebutuhan pelanggan, QFD akan mengakomodir masukan dan umpan balik pelanggan.

b. Efisiensi waktu, fokus persyaratan pelanggan yang telah diidentifikasi secara spesifik pada QFD akan mengurangi waktu pengembangan produk.

c. Orientasi pada kerja sama tim (Teamwork Oriented), semua keputusan dalam proses dilakukan dengan diskusi yang mendalam dan brainstorming.

d. Orientasi pada dokumentasi, dokumen yang komprehensif tentang semua data yang berkaitan dalam segala proses merupakan keluaran dari QFD yang sesuai dengan persyaratan pelanggan.

Validasi terhadap semua proses diatas dapat dilakukan dengan cara mengukur validitas konstrak, untuk melihat hubungan 
antara hasil pengukuran suatu alat tes dengan konsep teoritik yang dimilikinya dengan mencari korelasi antara masingmasing pertanyaan dengan skor total menggunakan persamaan teknik korelasi product moment sebagai berikut (Zulganef, 2006):

$r=\frac{n\left(\sum X Y\right)-\left(\sum X\right)\left(\sum Y\right)}{\sqrt{n \cdot \sum X^{2}-\left(\sum X\right)^{2}} \cdot \sqrt{n \cdot \sum Y^{2}-\left(\sum Y\right)^{2}}} \quad \cdots$

dengan:

$r$ : koefisien korelasi product moment

$n:$ jumlah responden

$X$ : skor pertanyaan/item

$Y$ : skor total pertanyaan

Validitas sebuah pertanyaan diukur dengan nilai angka korelasinya, jika angka korelasinya lebih besar dari nilai kritis pada tabel korelasi pada taraf signifikansi tertentu, maka pertanyaan tersebut dinyatakan valid. Uji reliabilitas merupakan uji sejauh mana hasil suatu pengukuran dapat dipercaya (Azwar, 2004), sehingga dapat disimpulkan bahwa alat ukur yang digunakan dalam penelitian memiliki kehandalan.

Membangun sofware sistem informasi dapat dilakukan dengan mengacu pada model waterfall, yaitu sebuah model klasik yang sistematis dan berurutan (Presman, 2002). Tahapan dalam membangun model tersebut adalah sebagai berikut:

a. Analisis kebutuhan, tahap ini seluruh kebutuhan software harus bisa didapatkan termasuk kegunaan yang diharapkan oleh pengguna dan batasan software.

b. Desain sistem, tahap ini menjelaskan apa yang harus dikerjakan kemudian bagaimana tampilannya, dilakukan sebelum melakukan coding.

c. Implementasi, tahap ini adalah fase penyusunan program dengan tahapan software dipecah menjadi modul-modul kecil untuk kemudian digabungkan lagi dalam tahap selanjutnya.

d. Integrasi dan uji coba, tahap ini menggabungkan modul-modul yang sudah dibuat kemudian dilakukan pengujian untuk mengetahui software yang dibuat telah sesuai desain dan mendeteksi eror.

e. Operasi dan pemeliharaan, tahap ini adalah menjalankan sofware yang sudah jadi serta melakukan proses pemeliharaan.

Proses membangun web tidak lepas dengan istilah Hypertext Markup Language $(H T M L)$ yaitu Sebuah bahasa pemrograman komputer yang digunakan untuk membangun web. HTML dapat digunakan dan diakses untuk menampilkan beragai sistem informasi. Informasi yang dimuat dalam mesin pencari web internet dan format hypertex ditulis ke dalam berkas format ASCII agar dapat memberikan tampilan wujud yang terintegrasi. Konsep kerja PHP disajikan dalam Gambar 1 berikut ini.

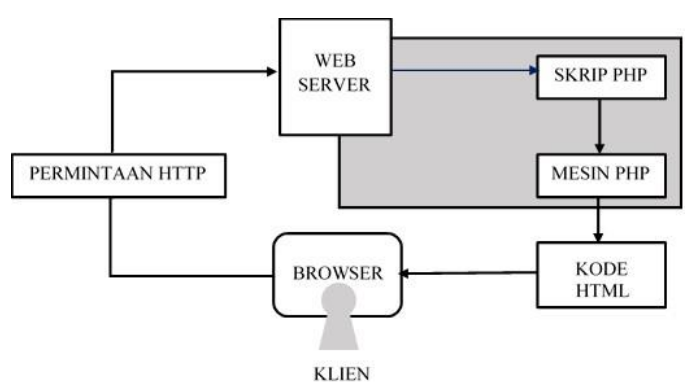

Gambar 1. Konsep kerja PHP (Arifudzaki dkk, 2010)

\section{METODOLOGI PENELITIAN}

Obyek dan Lokasi Penelitian adalah Program Studi Teknik Industri Fakultas Teknik Industri UPN "Veteran" Yogyakarta. Data diperoleh dari observasi dan pencatatan langsung terhadap pengguna, meliputi :

a. Data keinginan pengguna terhadap bentuk pelayanan yang diberikan oleh sistem informasi.

b. Data atribut kualitas pelayanan kepada pengguna yang diberikan oleh sistem informasi alumni.

Data dikumpulkan dengan cara menyebar kuisioner, wawancara dan tanya jawab lansung tentang masalah yang terkait dengan pengguna sebagai responden dan pihak perguruan tinggi. Langkah-langkah 
penelitian yang dilakukan adalah sebagai berikut:

a. Mengidentifikasi masalah, permasalahan dalam penelitian ini digali dengan cara melaksanaakan penelitian pendahuluan untuk memperoleh data pendahuluan tentang kajian yang akan diteliti.

b. Merumuskan masalah, rumusan masalah yang diangkat adalah bagaimana rancangan sistem informasi penelusuran alumni tracer study berbasis web yang dapat mendukung tersedianya data alumni.

c. Menetapkan tujuan penelitian, tujuan yang akan dicapai dalam penelitian ini adalah membangun sistem informasi penelusuran alumni tracer study berbasis web.

d. Mengkaji literatur, literatur yang dikaji adalah buku-buku teks, jurnal dan karya ilmiah hasil penelitian yang terkait dengan permasalahan pembuatan web dan penelusuran alumni.

e. Merancang sistem, sistem informasi dirancang dengan memperhatian dan mengakomodir kebutuhan database program studi khususnya data alumni, meliputi:

1) Identifikasi kebutuhan data alumni

2) Klarifikasi tujuan sistem

3) Penetapan fungsi-fungsi

4) Penyusunan kebutuhan

5) Penetapan karakteristik

6) Desain sistem

7) Pengkodean

f. Memvalidasi rancangan, validasi rancangan sistem informasi dengan kebutuhan data alumni yang mendukung tracer studi.

g. Menganalisis hasil, analisis hasil dilakukan untuk melihat kemudahan dan kelemahan dari sistem informasi penelusuran alumni setelah diuji cobakan dalam pendataan lapangan.

h. Menarik kesimpulan, kesimpulan dirumuskan terhadap hasil perancangan setelah diuji cobakan dengan data lapangan.

\section{ANALISIS DAN PEMBAHASAN}

Sasaran rancangan membangun sistem penelusuran alumni khususnya untuk profil Ikatan Alumni Teknik Industri UPN
"Veteran" Yogyakarta (IATI) merupakan sarana yang digunakan untuk mewadahi keberadaan alumni teknik industri UPN "Veteran" Yogyakarta. IATI diharapkan akan menjadi sarana penunjang peran universitas dalam melakukan analisis karakteristik dan profil lulusan. Peran IATI diharapkan dapat membantu lulusan dalam mendapatkan pekerjaan. Identifikasi kebutuhan dan keinginan user yang bertujuan sebagai informasi awal rancangan dilakukan kepada 70 responden.

Berdasarkan olah data dari kuesioner pendahuluan ini dapat diketahui tentang cara kerja sistem, lamanya waktu penyampaian dan penerimaan informasi, keluhan-keluhan yang dirasakan saat bekerja. Analisis kelayakan sistem untuk pendataan alumni yang sekarang dilaksanakan oleh prodi adalah sebagai berikut:

a. Aspek performansi, proses registrasi, verifikasi dan pengarsipan data alumni masih dilakukan dengan cara manual. Pendataan alumni dilakukan dengan cara alumni harus mengisi form yang disediakan secara manual (dengan kertas kerja), form isian tersebut kemudian diverifikasi oleh admin dan selanjutnya diarsip. Program sistem komputer yang digunakan sebagai sarana pengarsipan adalah excell.

b. Aspek informasi, sistem informasi masih menggunakan media kertas untuk proses registrasi alumni dan hanya bisa dilakukan di prodi.

c. Aspek ekonomi, pendataan alumni yang selama ini berjalan menggunakan biaya cukup tinggi, contoh penggunaan kertas untuk pencatatan alumni dan informasi lowongan kerja.

d. Aspek pengawasan, kontrol dalam pendataan alumni masih sederhana dan manual, keamanan dan ketersediaan data masih rentan terhadap kesalahan.

e. Aspek efisiensi, sistem penelusuran data yang sudah teregistrasi masih dilakukan dengan cara manual, sehingga butuh waktu lama dan tidak efisien.

f. Aspek pelayanan, pengguna data alumni jika membutuhkan dilayani dengan cara manual dan sederhana, data dicari satu per satu dalam arsip. Hal ini disebabkan 
adanya pengarsipan yang belum terkomputerisasi.

Berdasarkan analisis tersebut maka permasalahan akan menjadi acuan dalam membangun sistem yang baik. Analisis kebutuhan sistem untuk membangun sistem penelusuran alumni (tracer study) dilakukan dengan dua cara, kebutuhan yang pertama dilakukan dengan analisis kebutuhan fungsional (functional requirement). Kebutuhan fungsional ini mencakup proses yang harus dilakukan, informasi yang harus ada, dan fasilitas yang harus disediakan sesuai kebutuhan user.

Kebutuhan fungsional sistem dapat disajikan kedalam Gambar 2 berikut ini:

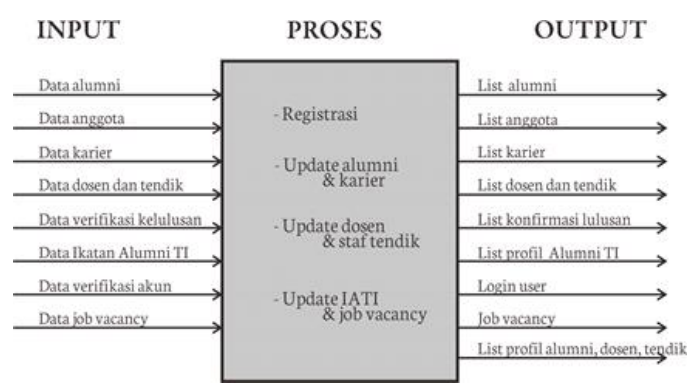

Gambar 2. Kebutuhan fungsional sistem
Berdasarkan Gambar 2, kebutuhan disesuaikan dengan kepentingan setiap user yang meliputi kebutuhan data alumni, data dosen dan tendik, data job vacancy alumni dan data IATI. Spesifikasi sistem yang akan dibuat ditentukan oleh kebutuhan user agar diperoleh informasi yang berguna dan sesuai kebutuhan.

Cara yang kedua untuk menganalisis sistem dilakukan dengan analisis kebutuhan non fungsional (non-functional requirements), tidak terkait langsung dengan rancangan sistem. Kebutuhan non-fungsional berisi properti perilaku dari sistem, diantaranya adalah reliability, portability, dan supportability.

Tahapan rancangan sistem yang pertama adalah mengidentifikasi kebutuhan pengguna untuk mengetahui menggali informasi dini rancangan yang aakan dibuat berdasarkan kebutuhan pengguna. Pertama dilakukan survei pendahuluan, dengan cara menggali informasi kebutuhan pengguna melalui kuisioner. Hasil survei pendahuluan tersebut disajikan dalam Tabel 1.

Tabel 1. Data survei pendahuluan kebutuhan pengguna

\begin{tabular}{|c|l|l|}
\hline No & \multicolumn{1}{|c|}{ Suara pengguna } & \multicolumn{1}{c|}{ Kebutuhan pengguna } \\
\hline 1 & Kesulitan akses informasi & Kemudahan sistem dalam mengakses informasi \\
\hline 2 & Proses mendapatkan informasi lama & Kecepatan sistem dalam penyampaian informasi \\
\hline 3 & Kesulitan mengoperasikan sistem & Kemudahan mengoperasikan sistem \\
\hline 4 & Sistem masih manual & Komputerisasi sistem \\
\hline 5 & Sistem kurang handal & Kehandalan sistem yang baik \\
\hline 6 & $\begin{array}{l}\text { Tampilan informasi tidak menarik } \\
\text { dan rapi }\end{array}$ & Kerapian dan tampilan informasi yang menarik \\
\hline
\end{tabular}

Setelah diketahui kebutuhan dasar pengguna, maka dilakukan penggalian informasi yang lebih dalam dari pengguna untuk dilanjutkan dengan memberi bobot rangking tingkat kepentingannya. Uji validasi dan reliabilitasnya terhadap data dilakukan sebelum merumuskan bobot paling dominan yang dibutuhkan untuk merancang sistem informasi.

Data uji validasi kuisioner pengguna menghasilkan uji sebagai berikut: nilai $r$ tabel $=0,158$ pada taraf nyata $5 \%$ dan derajad kebebasan $d f=68$, dengan demikian disebelah kirinya merupakan daerah kritisnya untuk pengujian satu arah. Hasil pengolahan data nilai $r$ hitung masingmasing parameter dari kepentingan pengguna sistem dan kepuasan pengguna sistem terhadap sistem informasi penelusuran alumni (tracer study) lebih besar nilainya dibandingkan dengan $r$ tabel. Nilai $r$ hitung lebih besar dari $r$ tabel, dengan demikian nilai $r$ hitung jatuh didaerah 
penerimaan $H_{0}$, dengan demikian dapat disimpulkan bahwa hasil kuisioner dari parameter kepentingan dan kepuasan pengguna sistem tersebut dinyatakan valid.

Reliabilitas kuisioner diuji menggunakan nilai Cronbach's Alpha didapatkan nilai uji sebesar $=0,913$ untuk parameter kepentingan pengguna, dan nilai uji sebesar $=0,841$ untuk parameter kepuasan pengguna sistem. Nilai uji tersebut lebih besar daripada nilai tabel, sehingga jatuh didaerah penerimaan $H_{0}$ dengan demikian disimpulkan bahwa hasil kuisioner terhadap kedua parameter reliabel.

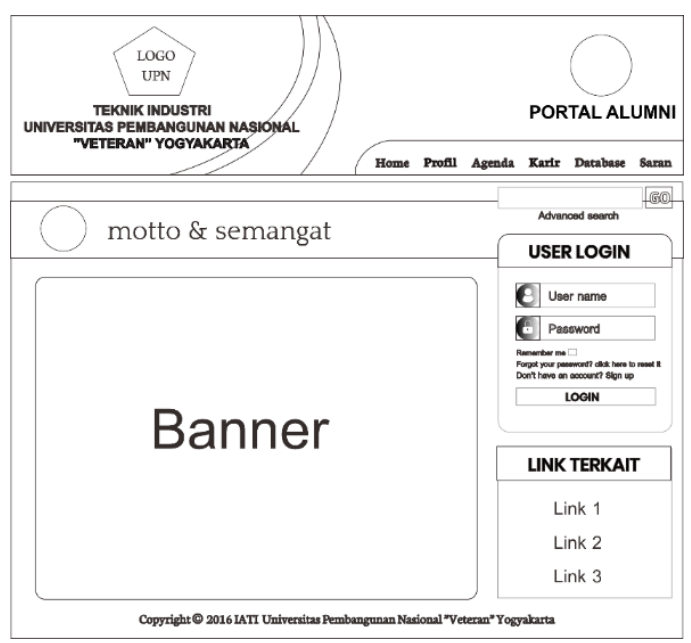

Gambar 3. Rancangan halaman utama sistem

Rancangan sistem dimulai dengan rancangan konseptual, 3 tahapan dalam perancangan konseptual yaitu klasifikasi tujuan, analisis fungsi, dan spesifikasi performansi. Setelah dilakukan rancangan konseptual dengan berbagai parameter dan atribut yang dipertimbangkan berdasarkan kebutuhan dan kepuasan pengguna sistem, maka dilanjutkan dengan perancangan sistem.

Perancangan sistem diawali dengan perencanaan sistem yang meliputi perencanaan software, hardware, operator, basis data, prosedur, dan jaringan komunikasi yang akan digunakan. Sofware menggunakan database MySQL dengan bahasa pemrograman PHP. Hardware menggunakan komputer intel pentium, operator direncanakan adalah admin dari prodi dan IATI, basis data meliputi data alumni, data dosen, data tendik, data job vacancy dan data-data lain yang diperlukan. Prosedur ditetapkan setip pengguna harus registrasi terlebih dahulu untuk diverifikasi dan ditetapkan hak akses sistem, jaringan komunikasi menggunakan jaringan internet untuk kemudahan dan keleluasaan jangkauan. Setelah beberapa rancangan dilakukan, maka untuk rancangan halaman utama disajikan sebagaimana dalam Gambar 3 diatas. Output hasil rancangan sistem penelusuran alumni (tracer study) yang dibangun disajikan dengan tampilan halaman utama, meliputi halaman utama (home), halaman profil IATI, halaman agenda kegiatan, karir, database, halaman registrasi alumni/akun. Tampilan halaman utama tersebut disajikan pada Gambar 4 sebagai berikut:

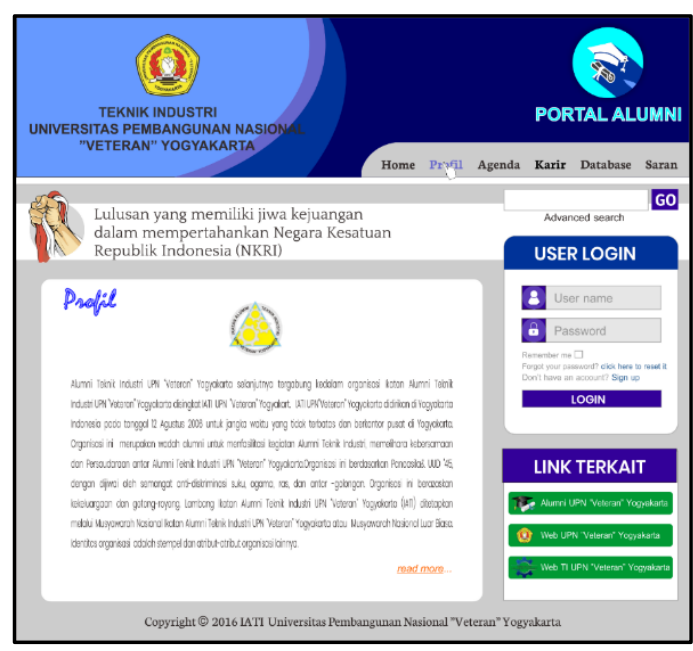

Gambar 4. Tampilan halaman utama sistem penelusuran alumni

\section{KESIMPULAN DAN SARAN}

Kesimpulan dari penelitian ini adalah:

1). Identifikasi kebutuhan pengguna adalah:
a. Kemudahan sistem mengakses informasi,
b. Kecepatan sistem menyampaikan informasi,
c. Kemudahan mengoperasikan sistem,
d. Komputerisasi sistem,
e. Kehandalan sistem yang baik, 
f. Kerapian dan tampilan informasi yang menarik.

2). Rancangan sistem yang dibangun dapat dijalankan dan memudahkan proses pengarsipan, pengolahan data alumni.

Saran yang dapat diberikan adalah:

Sistem ini masih dapat dikembangkan dengan mengoptimalkan Fitur-fitur dan link yang ada dalam sistem agar mudah dikenali oleh search engine.

\section{DAFTAR PUSTAKA}

Arifudzaki, B., Somantri, M., dan Adian, F.R., 2010, Aplikasi sistem informasi persediaan barang pada perusahaan ekspor hasil laut berbasis web, Jurnal Teknik Elektro TRANSMISI, Vol. 12, No. 4, hal. 138-144.

Arizyanty, R., 2009, Perancangan Sistem Informasi Pemesanan Produk Berbasis Web, Tugas Akhir, Teknik Industri, Universitas Pembangunan Nasional "Veteran" Yogyakarta, Yogyakarta.

Azwar, S., 2004, Reliabilitas dan Validitas, Pustaka Pelajar Offset, Yogyakarta.

Akao, Y., 1990. Quality Function Deployment: Integrating Customer Requirements into Product Design. Translated by Glenn H. Mazur. Productivity Press.

Cohen, L., 1995, Quality Function Development: How to Make QFD Work for You, Singapore, Addison Wesly Publising Company.

Cross, N., 1989, Engineering Design Methods: Strategies For Product Design, Second Edition, John Wiley \& Sons, New York.

Laudon, K. C.; Laudon, J. P. , 2007, Sistem Informasi Manajemen. Palgrave, Basingstoke.
Pressman, R.S., 2002, Rekayasa Perangkat Lunak: Pendekatan Praktis, Andi Offset, Yogyakarta.

Urban, G.L and Hauser, J.R., 1993, Design and Marketing of New Products. 2nd ed. Englewood Cliffs, NJ: Prentice-Hall.

Sutabri, T., 2012, Analisis Sistem Informasi, Ed. I, Andi Offset, Yogyakarta 